\title{
NUTRITIONAL EVALUATION OF ROSELLE (Hibiscus sabdariffa L.) AND ITS APPLICATION IN BISCUIT SUPPLEMENTATION
}

\author{
Walaa M. El-Sayed ${ }^{1 \star}$, El-Kalyoubi² M.H., Mostafa ${ }^{2}$ M.M. \\ and Salwa ${ }^{1}$ A. Farghal
}

1- Agric. Industrialization Unit, Desert Research Centre, Cairo, Egypt

2- Food Sci. Dept., Fac. of Agric., Ain Shams Univ., P.O. Box 68, Hadayek Shobra11241, Cairo, Egypt

${ }^{*}$ Corresponding author: w_mohamed2020@yahoo.com

Received 10 December, 2019

Accepted 12 January, 2020

\section{ABSTRACT}

Roselle (Hibiscus sabdariffa L.) plant was analyzed for its chemical and nutritional characteristics of plant parts (seeds, seeds cake, leaves, stems and roots) as well as the effect of the replacement of wheat flour with roselle powder at different ratios either from roselle seeds cake $(0,10,20$ and $30 \%)$ or roselle leaves powder $(0,2.5,5$ and $7.5 \%)$ on the nutritional and quality properties of biscuits. The obtained results proved that roselle seed, cake and leaves is a rich source of valuable nutrients, i.e., protein $(12.32-29.06 \%)$, lipids (4.45 $27.83 \%)$, ash (5.53 - 15.13\%) and crude fiber $(14.52-20.53 \%)$ as well as higher content of essential minerals. Potassium, calcium and phosphorus are to be the highest concentration in roselle parts, it ranged between 7.94-46.30 mg/g (potassium), $5.29-28.80 \mathrm{mg} / \mathrm{g}$ (calcium) and 3.23-22.10 $\mathrm{mg} / \mathrm{g}$ (phosphorus), other studied elements are at the lowest values. Total phenolic compounds ranged between 155.04-3288.33 ppm as gallic acid, so it was the highest in roselle leaves being 3288.33 ppm followed by stem (2086.78 ppm); however it could be used as natural antioxidant. In corporation of roselle cake or leaves powder in biscuit formula improved the nutritional profile and physical characteristics of biscuits. Increasing the incorporation of roselle cake or leaves powder, it increased the nutritive value of prepared biscuit. On the other hand, cocoa biscuit recorded the highest values of the physical properties than vanilla biscuit. Sensory evaluation revealed that the best replacement ratio was $10 \%$ of roselle cake and $2.5 \%$ of roselle leaves which gave suitable attributes for panelists which scored the highest
\end{abstract}

level of biscuit quality. From the obtained results, roselle could be become an excellent economic and valuable source of the nutritional factors which can be used in food supplementation. It is worth mentioning that, roselle seeds and cake are considered a good source of protein and can replace animal protein, especially for vegetarians.

Keywords: Roselle, Nutritional value, Mineral, Cookies, Biscuits

\section{INTRODUCTION}

Roselle (Hibiscus sabdariffa L.) is an annual botanical plant belonging to the Malvaceae family, which is one of the most common flower plants grown world-wide tropical and subtropical regions. It is locally known "Karkade". The plant has fibrous stems, small branches as well as bright red and acidic - tasting clayces (Fasoyiro et al 2005 and Tounkara et al 2011). Hibiscus species are native to Southern Asia and West Africa which can grow well under such adverse climate because of their low moisture demands, fertility requirements and tolerance to high temperatures as well as drought - resistant warm season annual (Gadwal and Naik, 2015). On the other hand, these plants have multifunctional properties with many attributes and considerable potential, however, the various parts have may useful applications like roselle calyces and petals of the flowers are extensively used to improve herbal drinks, cold and hot beverages as well as making jams and jellies. The roselle drink has been shown to be a good source of ascorbic acid. All plant parts are useful and consumed where the stem is exploited to produce fibers. The 
leaves are cooked like spinach in Africa which containing nutrients such as phosphorus, calcium, magnesium and potassium (Delgado-Vargas \& paredes-lopez, 2003; Atta et al 2010 and Karma et al 2017b).

The antioxidant capacity and other biological properties of roselle calyces extracts have been studied. (Tsai et al 2002 and Hirunpanich et al 2006).

Previous studies mentioned that the seeds can be used as potential source of proteins (El-Adawy and Khalil, 1994 and Al-Wandawi et al 1984) good source of the culinary oil (Nyam et al 2009). It is also an excellent source of fiber (Omabuwajo et al 2000) however; the seeds might be useful as low cost source of dietary fibre substitute in dietary supplement or food ingredient in food industry. Therefore, it will improve the daily intake of dietary fiber and over-come the fibre deficit.

Nyam et al (2009) showed that roselle seeds contain about $14.9 \%$ protein, $21 \%$ crude fibre, $15 \%$ oils and $36 \%$ carbohydrates as well as the oil contains the phytosterols and tocopherols which is known for its ability to reduce the absorption of dietary cholesterol when included in human diet (Jonse et al 2000). It could be mentioned that nutritional compositions of roselle plant vary depending on the variety location and environmental conditions where it was grown (Mariod et al 2013). In view of the mentioned studied for the nutritional and therapeutic characteristics and relative safety of Roselle as well as the natural antioxidants components, this plant may be used as a valuable nutritional source in the food industry and food supplemented products. Cookies is the convenient worldwide food, therefore, blending roselle powder with flour in value added products will greatly popularize roselle and exposing its rich nutritional potentials for overall health benefits. The aim of present investigation was to focus and shed light upon the nutritional value of roselle plant as an un traditional source and to evaluate its possibility utilization as a supplementary food product.

\section{MATERIAL AND METHODS}

Roselle (Hibiscus sabdariffa L.) plant was obtained from Siwa Research Station, Desert Research Center, Egypt, at harvesting season, 2017.

\section{Technological preparation}

Roselle plant was sorted out and cleaned from dust, stones and plant debris however; the roselle plant parts (seeds, cake, leaves, stems and roots) were separated according to Morton (1987) method. For predation seeds cake, oil was extracted from roselle seeds using Hydraulic pressure. The resulting roselle seeds cake were dried at $40^{\circ} \mathrm{C}$, milled and sieved to get powder $1 \mathrm{~mm}$. Roselle parts were packed in polyethylene bags and stored at $-20^{\circ} \mathrm{C}$ until used.

\section{Preparation of biscuit}

Biscuits were prepared by A.A.C.C. (2000) method No. 10-52 using the following recipe (100 g flour, $50 \mathrm{~g}$ sugar, $50 \mathrm{~g}$ shortening, $1.2 \mathrm{~g}$ baking powder, $22.5 \mathrm{~g}$ egg, $0.5 \mathrm{~g}$ vanilla and $10 \mathrm{~g}$ cocoa). For making biscuit sugars and shortening were creamed together then add eggs. The flour, salt and baking powder were sieved, added to mixture. It was rolled out with the help of rolling pin and dough of biscuits was cut with the help of biscuit cutter. These biscuits were baked at $160^{\circ} \mathrm{C}$ for 20 minutes and allowed to cool at room temperature for 10 minutes. Biscuits were packed in polyethylene for analysis (Kamal, 2015). To this formula, each roselle cake replaced with wheat flour by 0 , 10,20 and $30 \%$, however, roselle leaves replaced with wheat flour by $0,2.5,5$ and $7.5 \%$.

\section{Methods of analysis}

\section{Proximate composition}

Moisture, ash, crude protein (total nitrogen $\mathrm{X}$ 6.25), crude fiber and total lipids contents were determined according to A.O.A.C. (2010), while total carbohydrates were calculated by differences as:

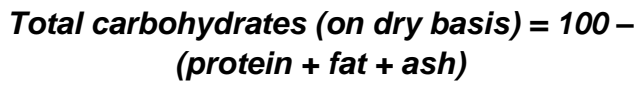

\section{Minerals composition}

Samples were digested in $100 \mathrm{~mL}$ microKjeldahl flask with $\mathrm{HNO}_{3} / \mathrm{HClO}_{4}$ until the solution became colorless. The samples were cooled and diluted to $50 \mathrm{~mL}$ in a volumetric flask with $0.1 \mathrm{M}$ $\mathrm{HCl}$. Sodium, potassium, calcium, magnesium, iron, zinc, manganese and copper were measured by atomic absorption spectrophotometry, (Garcia et al 1972) using a Varian spectra atomic absorption spectrophotometer. 


\section{Nutritional Evaluation of Roselle (Hibiscus sabdariffa L.) and its Application in Biscuit Supplementation}

\section{Physical properties of produced biscuits}

Average weight of six biscuits was recorded in grams using electronic balance. Biscuits volume was measured by grain sesame seed displacement method. Average thickness of biscuits was measured by stacking six biscuits and measuring height to nearest $\mathrm{cm}$. Width of biscuits was measured by laying six biscuits to edge, measuring nearest cm A.A.C.C. (2000).

\section{Diameter measurement (D)}

Six biscuits were placed edge to edge. The total diameters of the six biscuits were measured in $\mathrm{cm}$ by using a ruler. The biscuits were rotated at an angle of $90^{\circ} \mathrm{C}$ for duplicate reading. This was repeated once more and average diameter was reported in cm A.A.C.C. (2000).

\section{Thickness measurement $(\mathrm{T})$}

Six biscuits were placed on to be of one another. The total height was measurement in $\mathrm{cm}$ using a ruler. This process was repealed once more and average thickness was reported in $\mathrm{cm}$ A.A.C.C. (2000).

\section{Hardness}

Hardness $\left(\mathrm{mg} / \mathrm{cm}^{3}\right)$ was determined using a penetrometer tester (modal pillion Advanced, Force Gauge, AFG-500), as recommended by Bourne and Comstock (1986).

\section{The specific volume}

Specific volume was calculated according to equation below:

\section{Specific volume $\left(\mathrm{cm}^{3} / \mathrm{g}\right)=$ Biscuit volume $\left(\mathrm{cm}^{3}\right) /$ biscuit weight $(g)$}

\section{Spread factor (SF)}

The spread factor (SF) was calculated from the diameter and thickness values using the following formula:

$$
S F=D / T \times C F \times 10
$$

\section{Where}

SF: spread factor, D: diameter, T: thickness and $\mathrm{CF}$ is a correction factor at constant atmospheric pressure. Its value was 1.0 in this case according to Hussain et al (2006).

\section{Sensory evaluation of produced biscuits}

The Sensory assessment of the prepared biscuit samples were evaluated by 20 panelists of the staff Agriculture Industrial Unit, Desert Research Center, Mataria, Cairo. Panelists were asked to evaluate color, odor, taste, crispness, appearance and overall acceptability, of all samples according to the method described by ISO 8589 (1988).

\section{Statistical analysis}

All data were expressed as mean values. Statistical analysis was performed using one way analysis of variance or two way analysis of variance (ANOVA) followed by Duncan's Multiple Range Test with $P \leq 0.05$ being considered statistically significant Snedecor and Cochran, (1980). Correlation matrix was done according to Dewey and LU, (1959).

\section{RESULTS AND DISCUSSION}

\section{Proximate composition of different roselle or- gans}

The chemical composition of roselle plant parts (seeds, cake, leaves, stems and roots) was measured and the obtained results are shown in Table (1). Moisture content was the lowest in seeds (7.72\%) followed by roselle cake (8.48\%). However, the highest moisture content was recorded for leaves then stems and roots being 76.51, 75.45 and $55.97 \%$, respectively. Significant differences $(P \leq 0.05)$ were observed for the different parts of roselle plant for the major constituents, however, the results of proximate analysis showed that this plant is a rich source of valuable nutrients, protein content recorded higher in cake $(29.06 \%)$ followed by seeds $(26.24 \%)$ than the other parts (leaves, stem and roots) which obtained concentration between $4.31-12.32 \%$. Also, the same trend was noted for total lipids, so roselle seeds had the highest value $(27.83 \%)$ as shown in the table. According to the obtained data, seeds and cake proved the lower concentrations of ash and carbohydrates than the other parts of roselle plant.

As for crude fiber, it ranged between 14.52$38.81 \%$ among the roselle parts, however it showed the descending trend roots $(38.81 \%)$, stem $(30.81 \%)$, cake $(20.23 \%)$, seeds $(18.10 \%)$ and leaves $(14.52 \%)$. It could be mentioned that this plant become an excellent economic and valuable source of nutrients which can be used in food fortification. These findings are in agreement with that of Nzikou et al (2011), Tounkara et al (2013) and Soheir El-Deab \& Heba Ghamry (2017). 
Table 1. Chemical composition of different roselle organs

\begin{tabular}{|c|c|c|c|c|c|}
\hline Components (\%) & Seed & Seeds cake & Leaves & Stems & Roots \\
\hline Moisture content & $7.72^{\mathrm{e}}$ & $8.48^{\mathrm{d}}$ & $76.51^{\mathrm{a}}$ & $75.45^{\mathrm{b}}$ & $55.97^{\mathrm{c}}$ \\
Total lipids * $^{\mathrm{a}}$ & $27.83^{\mathrm{a}}$ & $9.09^{\mathrm{b}}$ & $4.45^{\mathrm{c}}$ & $2.09^{\mathrm{e}}$ & $3.19^{\mathrm{d}}$ \\
Proteins * $^{*}$ & $26.24^{\mathrm{b}}$ & $29.06^{\mathrm{a}}$ & $12.32^{\mathrm{c}}$ & $6.00^{\mathrm{d}}$ & $4.31^{\mathrm{e}}$ \\
Ash * $^{\text {Crude Fiber* }}$ & $5.53^{\mathrm{d}}$ & $5.63^{\mathrm{d}}$ & $15.13^{\mathrm{a}}$ & $10.30^{\mathrm{b}}$ & $7.48^{\mathrm{c}}$ \\
T. carbohydrates ** $^{*}$ & $18.10^{\mathrm{d}}$ & $20.53^{\mathrm{c}}$ & $14.52^{\mathrm{e}}$ & $30.81^{\mathrm{b}}$ & $38.81^{\mathrm{a}}$ \\
Polyphenols (as ppm gallic acid) & $40.40^{\mathrm{e}}$ & $56.22^{\mathrm{d}}$ & $68.10^{\mathrm{c}}$ & $81.61^{\mathrm{b}}$ & $85.02^{\mathrm{a}}$ \\
\hline
\end{tabular}

* determined as dry basis and ${ }^{* *}$ determined by difference and Means followed by different small letters in the same row (effect of treatments) are significantly by Duncan's multiple test $(P \leq 0.05)$.

Results obtained for total phenolic compounds revealed that there were significant differences $(P$ $\leq 0.05$ ) among the different parts of roselle plant, it ranged between 155.04-3288.33 ppm as gallic acid, which roselle leaves and stem had the higher concentration. Phenolic compounds play an important effect in plant constituents because it contributes to overall antioxidant activities (Khattak et al 2008). Therefore, roselle plant could be used as natural source for antioxidant; this indirectly increases the value of roselle. These results are in agree with Mohd-Esa et al (2010) and Karma \& Chavan (2017a).

\section{Mineral composition of different roselle organs}

Minerals elements content were measured in the different parts of roselle plant (seeds, cake, leaves, stem and roots) and the obtained results are presented in Table (2). It could be noted that potassium, calcium and phosphorus are to be the highest concentration for all parts, while magnesium and sodium had the lowest concentrations. These findings are agreed with that of Anhwange et al (2006) and Tounkara et al (2011). These elements play an important role in preventing deficiency diseases (Cissouma et al 2013). Results of micronutrients showed that iron had the highest value followed by zinc, however, manganese and copper had the lowest as shown in the table.
Proximate composition of biscuits as affected by supplementation with roselle cake and leaves

The effect of supplementation the wheat flour with roselle cake and leaves powder on the proximate chemical composition of biscuit was studied. Different ratios of roselle cake $(10,20$ and $30 \%$ ) were replaced in wheat flour formula, while leaves powder were added at 2.5, 5, 7.5\%. Two types of biscuit samples were prepared either the supplemented by cake or leaves powder with adding vanilla or cocoa as a taste improver. The obtained data in Table (3) showed slight increase in moisture content in treated samples with comparison by the control. Increasing the replacing ratios of wheat flour with roselle cake or leaves led to increase the nutrients percent in vanilla and cocoa biscuits, which it showed significant increase when the incorporation was done.

It could be noted from the data in Table (4), an incremental trend in the mineral composition in prepared biscuits when roselle cake or leaves were incorporated in flour formula due to the higher content of these elements of roselle than wheat flour. The biscuits possess higher nutritive profile in comparing by the control with significant increase in protein, fiber and ash as shown in Table (3). On the other hand, supplementation biscuit with roselle cake powder or leaves powder improved the nutrition value. Increasing the replacement ratio increased the minerals composition content. 
Nutritional Evaluation of Roselle (Hibiscus sabdariffa L.) and its Application in Biscuit Supplementation

Table 2. Mineral composition of different organs of roselle plant $(\mathrm{mg} / \mathrm{g})$

\begin{tabular}{|c|c|c|c|c|c|}
\hline \multirow{2}{*}{ Mineral } & \multicolumn{5}{|c|}{ Composition (mg/g) } \\
\cline { 2 - 6 } & Seeds & $\begin{array}{c}\text { Seeds } \\
\text { cake }\end{array}$ & leaves & stems & roots \\
\hline \multicolumn{7}{|c|}{ Macronutrients } \\
\hline Calcium (Ca) & 28.800 & 25.535 & 15.700 & 13.500 & 5.298 \\
Magnesium (Mg) & 5.664 & 3.166 & 4.000 & 4.789 & 4.600 \\
Potassium (K) & 46.300 & 17.119 & 8.390 & 7.940 & 14.450 \\
Sodium (Na) & 2.159 & 1.500 & 0.716 & 0.711 & 0.605 \\
Phosphorous (P) & 22.100 & 7.754 & 3.300 & 3.239 & 5.148 \\
\hline \multicolumn{7}{|c|}{ Micronutrients } & \\
\hline Iron (Fe) & 0.523 & 0.196 & 0.152 & 0.148 & 0.214 \\
Manganese (Mn) & 0.080 & 0.068 & 0.057 & 0.070 & 0.102 \\
Zinc (Zn) & 0.212 & 0.096 & 0.055 & 0.052 & 0.042 \\
Copper (Cu) & 0.088 & 0.023 & 0.025 & 0.018 & 0.028 \\
\hline
\end{tabular}

Table 3. Proximate composition of biscuits as affected by supplementation with roselle seeds cake and leaves

\begin{tabular}{|c|c|c|c|c|c|c|}
\hline Components $\%$ & $\begin{array}{l}\text { Moisture } \\
\text { content }\end{array}$ & Fats * & Proteins * & Ash * & $\begin{array}{l}\text { Crude } \\
\text { Fiber* }\end{array}$ & $\underset{\star \star}{\text { T. carbohydrates }}$ \\
\hline \multicolumn{7}{|c|}{ Biscuits produced by replacing different ratios of wheat flour with roselle seeds cake } \\
\hline control, V & $2.69^{e}$ & $25.89^{d}$ & $6.34^{f}$ & $0.59^{f}$ & 0.0299 & $67.18^{d}$ \\
\hline $10 \% \mathrm{R}, \mathrm{V}$ & $2.77^{e}$ & $26.05^{\mathrm{c}}$ & $7.00^{\mathrm{d}}$ & $1.01^{\mathrm{e}}$ & $0.853^{\mathrm{e}}$ & $65.94^{\mathrm{e}}$ \\
\hline $20 \% \mathrm{R}, \mathrm{V}$ & $2.37^{f}$ & $26.18^{\mathrm{b}}$ & $7.43^{c}$ & $1.37^{d}$ & $1.461^{d}$ & $65.02^{f}$ \\
\hline $30 \% \mathrm{R}, \mathrm{V}$ & $2.21^{\mathrm{g}}$ & $26.58^{a}$ & $7.88^{b}$ & $1.64^{b}$ & $2.384^{\mathrm{b}}$ & $63.90^{\mathrm{h}}$ \\
\hline control, C & $3.97^{a}$ & $23.65^{9}$ & $5.69^{h}$ & $1.30^{d}$ & $0.013^{h}$ & $69.36^{a}$ \\
\hline $10 \% R, C$ & $3.82^{b}$ & $24.25^{f}$ & $5.91^{g}$ & $1.49^{c}$ & $0.674^{f}$ & $68.35^{b}$ \\
\hline $20 \% \mathrm{R}, \mathrm{C}$ & $3.70^{c}$ & $24.29^{f}$ & $6.56^{e}$ & $1.71^{b}$ & $1.631^{\mathrm{c}}$ & $67.44^{c}$ \\
\hline $30 \% \mathrm{R}, \mathrm{C}$ & $3.50^{d}$ & $24.67^{e}$ & $8.09^{a}$ & $2.32^{\mathrm{a}}$ & $2.512^{\mathrm{a}}$ & $64.92^{\mathrm{g}}$ \\
\hline \multicolumn{7}{|c|}{ Biscuits produced by replacing different ratios of wheat flour with roselle leaves } \\
\hline control, V & $2.69^{9}$ & $25.89^{d}$ & $6.34^{d}$ & $0.59^{f}$ & $0.029^{9}$ & $67.18^{\mathrm{c}}$ \\
\hline $2.5 \% \mathrm{~L}, \mathrm{~V}$ & $2.79^{f}$ & $26.46^{\mathrm{b}}$ & $5.69^{f}$ & $1.09 \mathrm{e}$ & $0.252^{d}$ & $66.76^{\mathrm{d}}$ \\
\hline $5 \% \quad L, V$ & $3.06^{\mathrm{e}}$ & $27.44^{\mathrm{a}}$ & $5.69^{f}$ & $1.40^{\mathrm{c}}$ & $0.296^{c}$ & $65.47^{f}$ \\
\hline $7.5 \% \mathrm{~L}, \mathrm{~V}$ & $3.07^{e}$ & $27.46^{\mathrm{a}}$ & $7.00^{b}$ & $1.74^{b}$ & $0.533^{a}$ & $63.80^{\mathrm{g}}$ \\
\hline control, C & $3.97^{b}$ & $23.65^{9}$ & $5.69^{f}$ & $1.30^{d}$ & $0.013^{h}$ & $69.36^{a}$ \\
\hline $2.5 \% \mathrm{~L}, \mathrm{C}$ & $3.87^{c}$ & $24.85^{f}$ & $6.13^{e}$ & $1.44^{\mathrm{c}}$ & $0.104^{f}$ & $67.58^{b}$ \\
\hline $5 \% \quad L, C$ & $3.74^{d}$ & $25.46^{e}$ & $6.78^{c}$ & $1.71^{b}$ & $0.199^{e}$ & $66.05^{e}$ \\
\hline $7.5 \%$ L, C & $4.10^{a}$ & $26.20^{\mathrm{c}}$ & $8.75^{a}$ & $2.42^{\mathrm{a}}$ & $0.409^{b}$ & $62.63^{h}$ \\
\hline
\end{tabular}

* determined as dry basis, ${ }^{* *}$ determined by difference, $R=$ ratio of replacing wheat flour with roselle seeds cake, $L=$ ratio of replacing wheat flour with roselle leaves, $\mathrm{V}=$ biscuits with Vanilla and $\mathrm{C}=$ biscuits with cocoa and Means followed by different small letters in the same column (effect of treatments) are significantly by Duncan's multiple test $(P \leq 0.05)$. 
Table 4. Minerals composition of biscuits as affected by supplementation with roselle seeds cake and leaves $(\mathrm{mg} / \mathrm{g})$

\begin{tabular}{|c|c|c|c|c|}
\hline Samples & $\begin{array}{l}\text { Calcium } \\
\text { (Ca) }\end{array}$ & $\begin{array}{l}\text { Magnesium } \\
(\mathrm{Mg})\end{array}$ & Potassium (K) & $\begin{array}{c}\text { Phosphorous } \\
\text { (P) }\end{array}$ \\
\hline \multicolumn{5}{|c|}{ Biscuits produced by replacing different ratios of wheat flour with roselle seeds cake } \\
\hline control, V & 2.562 & 1.481 & 750 & 6.876 \\
\hline $10 \% \mathrm{R}, \mathrm{V}$ & 3.083 & 1.649 & 1000 & 9.300 \\
\hline $20 \% \mathrm{R}, \mathrm{V}$ & 3.203 & 2.561 & 1750 & 9.954 \\
\hline $30 \% \mathrm{R}, \mathrm{V}$ & 4.817 & 4.377 & 2000 & 13.570 \\
\hline control, C & 2.083 & 1.763 & 1500 & 7.771 \\
\hline $10 \% R, C$ & 3.199 & 1.237 & 1500 & 7.226 \\
\hline $20 \% \mathrm{R}, \mathrm{C}$ & 3.208 & 3.073 & 1750 & 11.660 \\
\hline $30 \% \mathrm{R}, \mathrm{C}$ & 3.747 & 3.660 & 2500 & 16.920 \\
\hline \multicolumn{5}{|c|}{ Biscuits produced by replacing different ratios of wheat flour with roselle leaves } \\
\hline control, V & 2.562 & 1.481 & 750 & 6.876 \\
\hline $2.5 \% \mathrm{~L}, \mathrm{~V}$ & 3.706 & 1.588 & 750 & 7.002 \\
\hline $5 \% \quad$ L, V & 4.507 & 1.710 & 2000 & 9.005 \\
\hline $7.5 \% \mathrm{~L}, \mathrm{~V}$ & 5.565 & 2.239 & 2000 & 9.217 \\
\hline control, C & 2.083 & 1.763 & 1500 & 7.771 \\
\hline $2.5 \% \mathrm{~L}, \mathrm{C}$ & 3.989 & 3.320 & 2000 & 9.353 \\
\hline $5 \% \quad L, C$ & 6.401 & 3.370 & 2250 & 10.470 \\
\hline $7.5 \% \mathrm{~L}, \mathrm{C}$ & 7.088 & 5.230 & 3250 & 15.070 \\
\hline
\end{tabular}

$\mathrm{R}=$ ratio of replacing wheat flour with roselle seeds cake, $\mathrm{L}=$ ratio of replacing wheat flour with roselle leaves, $\mathrm{V}=$ biscuits with Vanilla and $\mathrm{C}=$ biscuits with cocoa and Means followed by different small letters in the same column (effect of treatments) are significantly by Duncan's multiple test $(P \leq 0.05)$.

It could be noted that incorporation of leaves powder proved higher content of minerals than roselle cake powder, as well as cocoa biscuit showed, generally, the highest content than vanilla biscuit as shown in Table (4).

Physical characteristics of biscuits as affected by supplementation with roselle seeds cake and leaves

The estimation of physical characteristics of the prepared biscuits based on weight, volume thickness diameter and spread factor were carried out to ascertain the effect of replacing roselle cake or leaves on the physical attributes and properties in biscuits product. The results in Table (5) revealed an increment line for biscuits weight, volume, specific volume, diameter and spread ratio in samples fortified with roselle cake and added vanilla as taste improver with compared with the control, and these properties affected by the increase in level of replacing ratio. As for cocoa biscuits, it could be noted that there was a decrease in biscuit weight with increasing the replacement of roselle cake, however, the volume did not affect and this led to increase the specific volume of biscuit as shown in the table. Spread factor of biscuit was increased as a result of increase the diameter with any variation for thickness, so cocoa biscuit recorded higher values in thickness and lower values than vanilla biscuits. Concerning to hardness property, it could be noted that there were significant differences $(P$ $\leq 0.05$ ) among the biscuit samples with increasing the replacing ratios. On the other hand, it could be observed the same previous trends for physical properties of biscuit samples fortified with roselle seeds cake, it where also noted for biscuit fortified with roselle leaves powder. 
Table 5. Physical characteristics of biscuits as affected by supplementation with roselle seeds cake and leaves

\begin{tabular}{|c|c|c|c|c|c|c|c|}
\hline Components & $\begin{array}{l}\text { Weight } \\
\text { (g) }\end{array}$ & $\begin{array}{l}\text { Volume } \\
\left(\mathrm{cm}^{3}\right)\end{array}$ & $\begin{array}{l}\text { Specific } \\
\text { volume } \\
\left(\mathrm{cm}^{3} / \mathrm{g}\right)\end{array}$ & $\begin{array}{c}\text { Thickness } \\
(\mathrm{cm})\end{array}$ & $\begin{array}{l}\text { Diameter } \\
\text { (cm) }\end{array}$ & $\begin{array}{l}\text { Spread } \\
\text { factor }\end{array}$ & $\begin{array}{l}\text { Hardness } \\
\left(\mathrm{mg} / \mathrm{cm}^{3}\right)\end{array}$ \\
\hline \multicolumn{8}{|c|}{ Biscuits produced by replacing different ratios of wheat flour with roselle seeds cake } \\
\hline control, V & $6.58^{\mathrm{d}}$ & $0.90^{c}$ & $0.137^{\mathrm{b}}$ & $0.80^{\mathrm{b}}$ & $3.80^{d}$ & $47.50^{d}$ & $1645^{\mathrm{e}}$ \\
\hline $10 \% R, V$ & $6.75^{\mathrm{c}}$ & $0.90^{\mathrm{c}}$ & $0.133^{\mathrm{b}}$ & $0.80^{\mathrm{b}}$ & $3.90^{\mathrm{c}}$ & $48.75^{\mathrm{c}}$ & $1650^{\text {de }}$ \\
\hline $20 \% \mathrm{R}, \mathrm{V}$ & $7.16^{\mathrm{b}}$ & $1.10^{\mathrm{b}}$ & $0.154^{\mathrm{b}}$ & $0.80^{\mathrm{b}}$ & $4.00^{\mathrm{b}}$ & $50.00^{\mathrm{b}}$ & $1785^{b}$ \\
\hline $30 \% \mathrm{R}, \mathrm{V}$ & $7.36^{a}$ & $1.50^{\mathrm{a}}$ & $0.204^{a}$ & $0.80^{\mathrm{b}}$ & $4.20^{\mathrm{a}}$ & $52.50^{\mathrm{a}}$ & $2015^{a}$ \\
\hline control, C & $6.67^{c}$ & $0.90^{c}$ & $0.135^{\mathrm{b}}$ & $0.90^{\mathrm{a}}$ & $3.50^{\mathrm{g}}$ & $38.88^{\mathrm{h}}$ & $1440^{f}$ \\
\hline $10 \% R, C$ & $6.48^{\mathrm{e}}$ & $0.90^{c}$ & $0.139^{b}$ & $0.90^{a}$ & $3.60^{f}$ & $40.00^{g}$ & $1655^{d}$ \\
\hline $20 \% \mathrm{R}, \mathrm{C}$ & $6.28^{f}$ & $0.90^{c}$ & $0.143^{b}$ & $0.90^{\mathrm{a}}$ & $3.70^{\mathrm{e}}$ & $41.11^{\dagger}$ & $1765^{c}$ \\
\hline $30 \% \mathrm{R}, \mathrm{C}$ & $6.02^{g}$ & $0.90^{c}$ & $0.150^{\mathrm{b}}$ & $0.90^{a}$ & $3.80^{d}$ & $42.22^{\mathrm{e}}$ & $2015^{a}$ \\
\hline \multicolumn{8}{|c|}{ Biscuits produced by replacing different ratios of wheat flour with roselle leaves } \\
\hline control, V & $6.58^{\mathrm{e}}$ & $0.90^{c}$ & $0.137^{b}$ & $0.80^{\mathrm{b}}$ & $3.80^{c}$ & $47.50^{\mathrm{b}}$ & $1645^{c}$ \\
\hline $2.5 \% \mathrm{~L}, \mathrm{~V}$ & $7.21^{\mathrm{c}}$ & $0.90^{c}$ & $0.125^{c}$ & $0.80^{\mathrm{b}}$ & $3.90^{\mathrm{b}}$ & $48.75^{a}$ & $1390^{f}$ \\
\hline $5 \% \quad L, V$ & $7.39^{b}$ & $1.00^{\mathrm{b}}$ & $0.135^{b}$ & $0.80^{\mathrm{b}}$ & $3.90^{\mathrm{b}}$ & $48.75^{a}$ & $1430^{e}$ \\
\hline $7.5 \%$ L, V & $7.79^{a}$ & $1.10^{\mathrm{a}}$ & $0.141^{b}$ & $1.00^{\mathrm{a}}$ & $4.20^{\mathrm{a}}$ & $42.00^{d}$ & $2200^{\mathrm{a}}$ \\
\hline control, C & $6.67^{d}$ & $0.90^{c}$ & $0.135^{\mathrm{b}}$ & $0.90^{\mathrm{a}}$ & $3.50^{\mathrm{e}}$ & $38.88^{\mathrm{e}}$ & $1440^{d}$ \\
\hline $2.5 \% \mathrm{~L}, \mathrm{C}$ & $6.55^{\mathrm{e}}$ & $0.80^{d}$ & $0.122^{c}$ & $0.80^{\mathrm{b}}$ & $3.70^{d}$ & $46.25^{c}$ & $760^{g}$ \\
\hline $5 \% \quad$ L, C & $6.50^{\mathrm{e}}$ & $0.90^{c}$ & $0.138^{b}$ & $0.80^{\mathrm{b}}$ & $3.70^{d}$ & $46.25^{c}$ & $1655^{b}$ \\
\hline $7.5 \% \mathrm{~L}, \mathrm{C}$ & $5.30^{f}$ & $0.92^{b c}$ & $0.174^{a}$ & $1.00^{\mathrm{a}}$ & $3.80^{c}$ & $38.00^{f}$ & $1660^{b}$ \\
\hline
\end{tabular}

$\mathrm{R}=$ ratio of replacing wheat flour with roselle seeds cake, $\mathrm{L}=$ ratio of replacing wheat flour with roselle leaves, $\mathrm{V}=$ biscuits with Vanilla and $\mathrm{C}=$ biscuits with cocoa and Means followed by different small letters in the same column (effect of treatments) are significantly by Duncan's multiple test $(P \leq 0.05)$.

Sensory characteristics of biscuits as affected by supplementation with roselle seeds cake and leaves

The sensory evaluation is considering the important index for potential consumer predilection. The sensory properties of biscuit samples prepared by replacing wheat flour with different ratios of roselle cake $(10,20$ and $30 \%)$ or with roselle leaves powder $(2.5,5$ and $7.5 \%)$ was carried out and the obtained results are shown in Table (6). It could be noted that biscuit characteristics were affected by the increase in the replacing ratios. Significant differences were noted for taste, odor and appearance among the biscuit samples. Appearance of vanilla biscuits was the least preferred because the color was pale as compared with control which observed like burnt after baking due to the high ratio of roselle incorporation into biscuit making. Cocoa biscuits showed higher scores than the vanilla biscuits as shown in table. The same trend was observed when the wheat flour replaced with roselle leaves powder to produce biscuits. Generally, the replacement of wheat flour by roselle cake improved the overall acceptability of biscuit; however, the best ratio of replacement was $10 \%$ which gave suitable attributes for panelist. On the other hand, the replacement of wheat flour with $2.5 \%$ of roselle leaves powder improved the biscuits characteristics and the overall acceptability for panelist. 
Table 6. Sensory characteristics of biscuits as affected by supplementation with roselle seeds cake and leaves

\begin{tabular}{|c|c|c|c|c|c|c|}
\hline Sample & Taste & Odor & color & Appearance & Crispness & $\begin{array}{c}\text { Overall } \\
\text { acceptability }\end{array}$ \\
\hline \multicolumn{7}{|c|}{ Biscuits produced by replacing different ratios of wheat flour with roselle seeds cake } \\
\hline control, V & $8.40^{f}$ & $8.60^{d}$ & $8.20^{c}$ & $8.70^{d}$ & $8.40^{\mathrm{e}}$ & $8.35^{\mathrm{e}}$ \\
\hline $10 \% R, V$ & $9.35^{\mathrm{de}}$ & $9.45^{c}$ & $9.15^{\mathrm{a}}$ & $9.65^{a}$ & $9.45^{c}$ & $9.35^{\mathrm{b}}$ \\
\hline $20 \% R, V$ & $9.40^{\mathrm{cd}}$ & $9.55^{\mathrm{b}}$ & $8.65^{\mathrm{b}}$ & $9.45^{\mathrm{b}}$ & $9.55^{\mathrm{b}}$ & $9.25^{c}$ \\
\hline $30 \% \mathrm{R}, \mathrm{V}$ & $9.85^{\mathrm{a}}$ & $9.70^{\mathrm{a}}$ & $8.40^{c}$ & $9.20^{c}$ & $9.70^{\mathrm{a}}$ & $9.05^{d}$ \\
\hline control, C & $8.30^{9}$ & $8.20^{\mathrm{e}}$ & $8.35^{\mathrm{bc}}$ & $8.50^{e}$ & $8.15^{\dagger}$ & $8.30^{\mathrm{e}}$ \\
\hline $10 \% R, C$ & $9.30^{\mathrm{e}}$ & $9.55^{\mathrm{b}}$ & $9.35^{\mathrm{a}}$ & $9.50^{\mathrm{b}}$ & $9.35^{d}$ & $9.55^{\mathrm{a}}$ \\
\hline $20 \% R, C$ & $9.45^{\mathrm{c}}$ & $9.60^{\mathrm{b}}$ & $9.40^{\mathrm{a}}$ & $9.50^{b}$ & $9.50^{\mathrm{bc}}$ & $9.40^{\mathrm{b}}$ \\
\hline $30 \% \mathrm{R}, \mathrm{C}$ & $9.55^{\mathrm{b}}$ & $9.60^{b}$ & $9.45^{\mathrm{a}}$ & $9.50^{\mathrm{b}}$ & $9.50^{\mathrm{bc}}$ & $9.35^{\mathrm{b}}$ \\
\hline \multicolumn{7}{|c|}{ Biscuits produced by replacing different ratios of wheat flour with roselle leaves } \\
\hline control, V & $8.40^{f}$ & $8.60^{e}$ & $8.20^{f}$ & $8.70^{f}$ & $8.40^{\mathrm{d}}$ & $8.35^{\mathrm{d}}$ \\
\hline $2.5 \% \mathrm{~L}, \mathrm{~V}$ & $9.00^{c}$ & $9.60^{\mathrm{a}}$ & $9.30^{\mathrm{b}}$ & $9.70^{\mathrm{a}}$ & $9.40^{\mathrm{b}}$ & $9.40^{\mathrm{b}}$ \\
\hline $5 \% \quad L, V$ & $8.90^{\mathrm{d}}$ & $9.55^{\mathrm{a}}$ & $9.15^{\mathrm{c}}$ & $9.35^{d}$ & $9.55^{\mathrm{a}}$ & $9.35^{\mathrm{b}}$ \\
\hline $7.5 \% \mathrm{~L}, \mathrm{~V}$ & $8.55^{\mathrm{e}}$ & $9.40^{\mathrm{b}}$ & $8.60^{d}$ & $9.20^{\mathrm{e}}$ & $9.55^{\mathrm{a}}$ & $9.20^{\mathrm{c}}$ \\
\hline control, C & $8.30^{9}$ & $8.20^{f}$ & $8.35^{\mathrm{e}}$ & $8.50^{\mathrm{g}}$ & $8.15^{\mathrm{e}}$ & $8.30^{d}$ \\
\hline $2.5 \% \mathrm{~L}, \mathrm{C}$ & $9.40^{\mathrm{b}}$ & $9.55^{\mathrm{a}}$ & $9.40^{\mathrm{a}}$ & $9.55^{b}$ & $9.55^{\mathrm{a}}$ & $9.55^{\mathrm{a}}$ \\
\hline $5 \% \quad$ L, C & $9.45^{\mathrm{b}}$ & $9.25^{c}$ & $9.30^{\mathrm{b}}$ & $9.45^{\mathrm{c}}$ & $9.45^{b}$ & $9.15^{c}$ \\
\hline $7.5 \% \mathrm{~L}, \mathrm{C}$ & $9.65^{a}$ & $9.05^{d}$ & $9.20^{c}$ & $9.35^{d}$ & $9.15^{c}$ & $9.15^{\mathrm{c}}$ \\
\hline
\end{tabular}

$R=$ ratio of replacing wheat flour with roselle seeds cake, $L=$ ratio of replacing wheat flour with roselle leaves, $V=$ biscuits with Vanilla and $\mathrm{C}=$ biscuits with cocoa and Means followed by different small letters in the same column (effect of treatments) are significantly by Duncan's multiple test $(\mathrm{P} \leq 0.05)$

\section{CONCLUSION}

Roselle seed is a rich source of valuable nutrients. Also, its high concentration of phenolic compounds, therefore, it could be used as natural antioxidant. On the other hand the obtained results showed that roselle could be become an excellent economic and valuable source of the nutritional factors which can be used in food supplementation

\section{REFERENCES}

A.A.C.C. 2000. American Association of Cereal chemists. Approved Methods of the AACC. $10^{\text {th }}$ ed. American Association of cereal chemists, St., Paul, Minnesota, USA.

Al-Wandawi H., Al-Shaikhly $K$. and AbdulRahman M. 1984. Roselle seed: A new protein source. J. Agric. Food Chem., 32, 510-512.
Anhwange B., Ajibola V. and Okibe F. 2006. Nutritive value and anti-nutritional factors in $\mathrm{Hi}$ biscus sabdariffa. J. Fish. Int., 1, 2-4.

A.O.A.C. 2010. Association of Official Analysis Chemists Official Methods of Analytical $19^{\text {th }}$ ed. Maryland, USA.

Atta S., Diallo A.B., Sarr B., Bakasso Y., Saadou M. and Glew R.H. 2010. Variation in macroelements and protein contents of roselle (Hibiscus sabdariffa L.) from Niger. African J. of Food Agric. Nutrition and Development, 10(6), 2707-2718.

Bourne M.C. and Comstock S.H. 1986. Effect of firmness of thermally processed fruits and vegetables. J. Food, Sci., 51, 531-533.

Cissouma A., Tounkara F., Nikoo M., Yang N. and Xu X. 2013. Physico Chemical Properties and Antioxidant Activity of Roselle Seed Extracts. Advance J. of Food Sci. and Technology 5(11), 1483-1489. 

in Biscuit Supplementation

Delgado-Vargas F. and Parcedes-Lopez 0 . 2003. Natural Colorants for Food and nutraceutical uses. CRC Press, LLC: Boca Raton, FL, $344 \mathrm{p}$.

Dewey D.R. and LU K.H. 1959. A correlation and path coefficient analysis of components of crested wheat grass seed production. Agronomy J., 51(9), 515-518.

El-Adawy T.A. and Khalil A.H. 1994. Characteristics of Roselle seeds as a new source of protein and lipid. J. Agric. Food Chem., 42(9), 1896-1900.

Fasoyiro S.B., Babalola S.O. and Owosibo T. 2005. Chemical Composition and Sensory Quality of Fruit-Flavoured Roselle (Hibiscus sabdariffa) Drinks, World J. of Agric. Sci., 1(2), 161-164.

Gadwal R. and Naik G. 2015. Studies on physicchemical properties and fatty acid profile of seed oil from two Hibiscus Species. World J. of Pharmaceutical Research 4(2), 1573-1583.

Garcia W.J., Blessin C.W. and Inglett G.E. 1972. Mineral constitutents in corn and wheat germ by atomic absorption spectroscopy. Cereal Chem., 49, 158-167.

Hirunpanich V., Utaipat A., Molales N.P., Bunyapraphtsala N., Sato H. and Herunsale A. 2006. Hypocholesterolemic and antioxidant effects of aqueous extracts from the dried calyx of Hibiscus sabdariffa L. in hypercholesterolemic rats. J. of Ethnopharmacology, 103, 252260.

Hussain S., Anjum F.M., Butt M.S., Khan M.I. and Asghar A. 2006. Physical and sensoric attributes of flaxseed flour supplemented cookies. Turk J. Biol. 30, 87-92.

ISO 8589. 1988. Sensory analysis. General guidance for design of test rooms. Standard no. 8589. Geneva, Switzerland.

Jones P.J., Raeini-Sarjaz M., Ntanios F.Y., Vanstone C.A., Feng J.Y. and Parsons W.E. 2000. Modulation of plasma lipid levels and cholesterol kinetics by phytosterol versus phytostanol esters. J. Lipid Res. 41, 697-705.

Kamal T. 2015. An Investigation on the Preparation of Containing Low Caloric Biscuits with Supplementation of Dietary Fiber. J. Food Process Technol., 6(6), 1-5.

Karma B.R. and Chavan U.D. 2017a. Antioxidant Activity and Nutritional Value of Roselle Seeds Flour. Int. J. Curr. Microbiol. App. Sci., 6(4), 2654-2663.
Karma B.R., Chavan U.D., Pawar G.H. and Gaikwad R.S. 2017b. Nitrogen Solubility and Functional Properties of Roselle Seed Flour. Int. J. Curr. Microbiol. App. Sci., 6(8), 11311139.

Khattak K.F., Simpson T.J. and Ihasnullah M. 2008. Effect of gamma irradiation on the extraction yield, total phenoic content and free radicalscavenging activity of Nigella sativa seed. Food Chem., 110, 967-972.

Mariod A.A., Suryaputra S., Hanafi M., Rohmana T., Kardono L. and Herwan T. 2013. Effect of diffrent processing technioues on Indonesian Roselle (Hibiscus radiates) seed constituents. Acta. Sci. Pol Technol, 12(4), 359-364.

Mohd-Esa N., Hern F.S., Ismail A. and Yee C.L. 2010. Antioxidant activity in different parts of roselle (Hibiscus sabdariffa L.) extracts and potential exploitation of the seeds. Food Chemistry 122, 1055-1060.

Morton J.F. 1987. Roselle. In: "Fruits of Warm Climates", ed. C.F. Karma and Chavan 2017. pp. 2654-2663.

Nyam K.L., Tan C.P., Lai O.M., Long K. and Man Y.B.C. 2009. Physicochemical properties and bioactive compounds of selected seed oils. LWT - Food Sci. Technol., 42, 1396-1403.

Nzikou J.M., Bouanga-Kalou G., Matos L., Ganongo-Po F.B., Mboungou-Mboussi P.S., Moutoula F.E., Panyoo-Akdowa E., Silou T.H. and Desobry S. 2011. Characteristics and Nutritional Evaluation of seed oil from Roselle (Hibiscus sabdariffa L.) in Congo-Brazzaville. Curr. Res. J. Biol. Sci., 3(2), 141-146.

Omobuwajo, T.O., Sanni L.A. and Balami Y.A. 2000. Physical properties of sorrel (Hibiscus sabdariffa ) seeds. J. Food Eng., 45, 37-41.

Snedecor G.W. and Cochran W.G. 1980. Statistical methods $7^{\text {th }}$ ed. Lowa State Univ., Press, Ames, lowa, USA.

Soheir El-Deab M. and Heba Ghamry E. 2017. Nutritional Evaluation of Roselle Seeds Oil and Production of Mayonnaise. Int. J. of Food Sci. and Nutrition Engineering, 7(2), 32-37.

Tounkara F., Amadou I., Le G.W. and Shi Y.H. 2011. Effect of boiling on the physicochemical properties of Roselle seeds (Hibiscus sabdariffa L.) cultivated in Mali. African J. of Biotechnology, 10(79), 18160-18166.

Tsai P.J., Mc Intosh J., Pearce P., Camden B. and Jordan B.R. 2002. Anthocyanin and antioxidant capacity in Roselle ( $H$. sabdariffa L.) extract. Food Res. Int. 35, 351-356. 


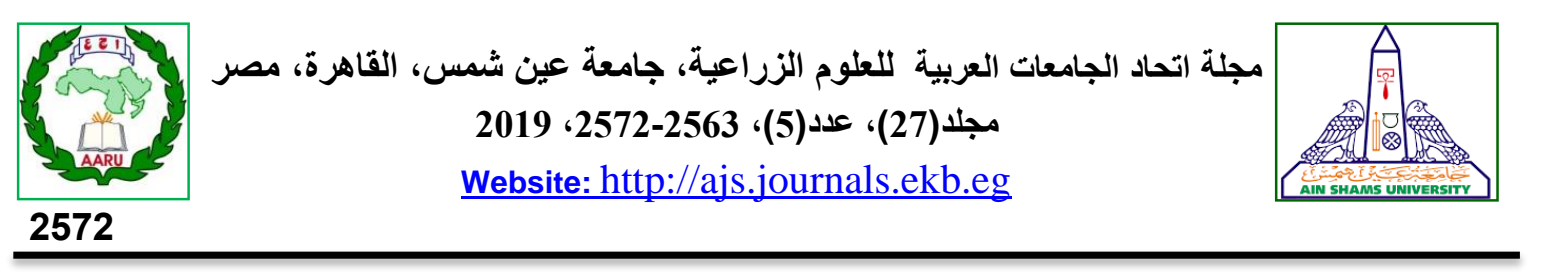

التقييم الغذائي للكركديه (Hibiscus sabdariffa L.) وتطبيقه في تدعيم البسكويت

[203]

$$
\begin{aligned}
& \text { ولاء محمد السيد1" - ممدوح حلمي القليوبيى2 - محمد مجدي مصطفى2 - سلوي أمين فرغل1 } 1
\end{aligned}
$$

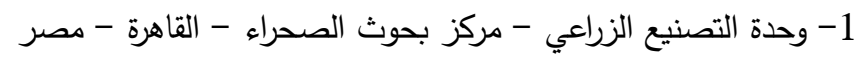

$$
\begin{aligned}
& \text { 2- قسم علوم أغذية - كلية الزراعة - جامعة عين شمس - ص.ب. } 68 \text { - حدائق شبرا } 11241 \text { - القاهرة - مصر }
\end{aligned}
$$

*Corresponding author: w_mohamed2020@yahoo.com

Received 10 December, 2019

Accepted 12 January, 2020

كمواد مضاد للأكسدة طبيعيه. أدى إستبدال مسحوق

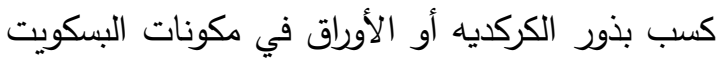

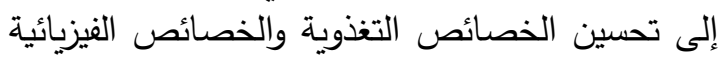

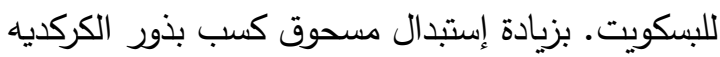

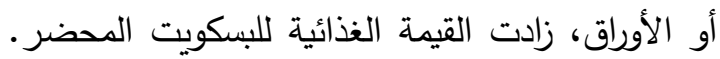

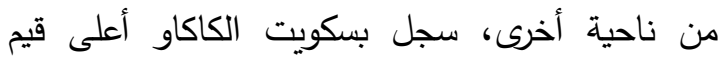

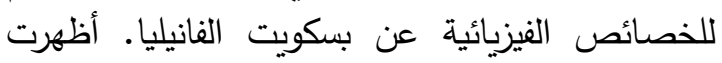

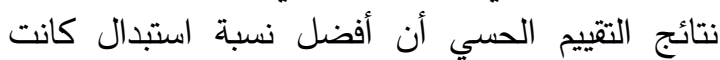

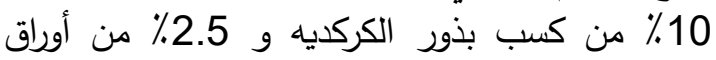

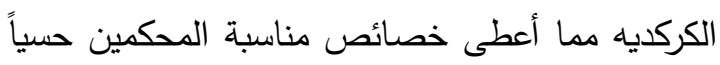
الذين سجلوا أعلى مستوى لجودة البسكويت. من النتائج

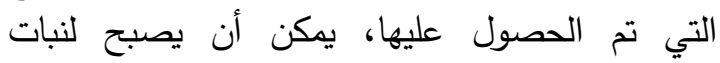

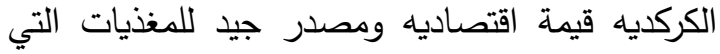
يمكن استخدامها في المكملات الغذائية. تجدر الإثارة

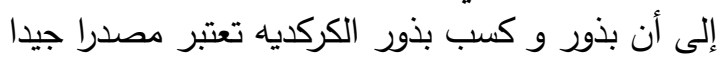

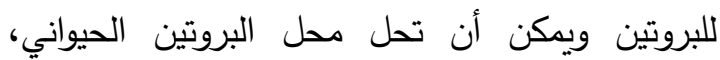
وخاصة للنباتيين.

الكلمات الدالة: الكركديه، القيمة الغذائية، المعادن،

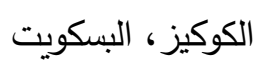

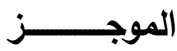

تم تحليل الخصائص الكيميائية والتغذوية للأجزاء النباتية المختلفة (البذور، الكيك، الأوراق، السيقان، النيان، والجذور) لنبات كركديه (Hibiscus sabdariffa L.) وأظهرت النتائج أن بذور النّريه (الكركديه، كسب البذور

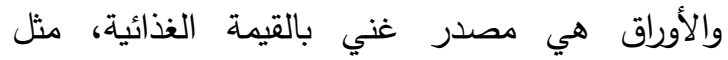

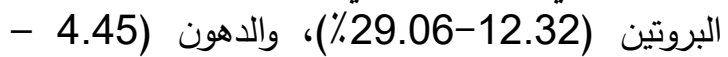

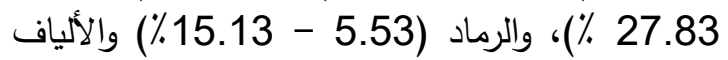
الخام (14.52 - 20.53 \% \% الرماد (53) وكذلك محتوى أعلى

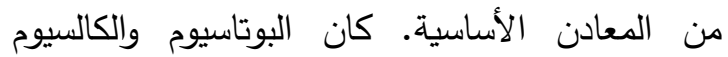
والفوسفور هم أعلى تركيز في أجزاء الكركديه، حيث الانيانية

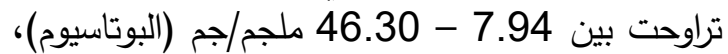

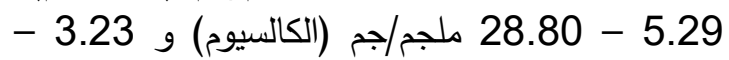

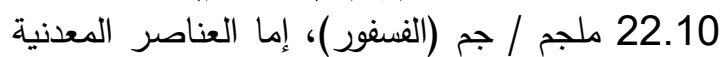
الأخرى كانت ذات قيم منخفضة. تراوحت المن المركبات

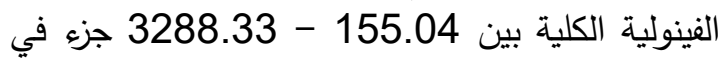
المليون كحمض الجاليك، لذلك كانت أعلى نسبة في

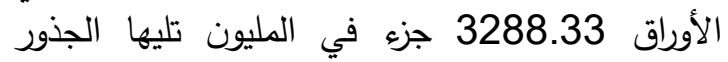

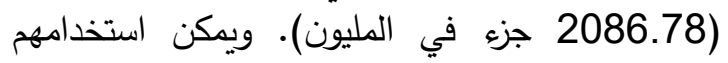

